\title{
Father, Son, Wife, Husband: Philanthropy as Exchange and Balance
}

\author{
Kwok-bun Chan
}

Published online: 11 June 2010

(c) The Author(s) 2010. This article is published with open access at Springerlink.com

\begin{abstract}
This essay attempts to use exchange and balance theories to explain philanthropy. For exchange, such theoretical components as attractions or rewards, costs, barriers and alternatives are invoked to make sense of the biography of a Chinese philanthropist in Hong Kong who donated two schools to remember his father and wife. The balance theory was also used, which argues that people do not seek to maximize their pleasure or to minimize their pain, but to balance, advancing one purpose or concern without neglecting the other-to enhance their well-being and to act morally. The essay argues that the case study method is most able to handle complex behaviour and complex lives. It concludes with a plea for more active use of social theory in research on philanthropy as moral and economic behavior embedded in the social contexts of family, marriage and community.
\end{abstract}

Keywords Philanthropy - Exchange and balance . Family and economics - Social theory and methodology . Life course case study

It is the intent of this essay to explain the motivation of altruism and philanthropy within the frameworks of two theoretical approaches: exchange theory and balance

This essay is a revision of a keynote delivered at Conference "The Future of Chinese Philanthropy in Asia Between Continuity and Change" jointly organized by Lee Kong Chian School of Business and Wee Kim Wee Centre, Singapore Management University, Singapore, 13 April 2009.

K. Chan $(\bowtie)$

Department of Sociology, Hong Kong Baptist University,

Kowloon Tong, Hong Kong

e-mail: ckb@hkbu.edu.hk theory. The desire is to bear social theory on the analysis of economic behavior within the context of marital and familial relations, while also resorting to insights of family sociology and sociology of emotions, and of rationality. The methodology chosen here is the case study method: construction of a life history narrative offered by a philanthropist in a long, indepth, face-to-face interview, onsite visits of his schools, and prior conversations with as well as naturalistic observations of him on many diverse social occasions. This combination of methods used over a course of several years to gain intimacy with a person's life is a productive way to make sense of such complex human behavior as altruism and philanthropy. As such, details of the philanthropist's life are displayed in the narrative of this essay in an attempt to examine a complex behavior within the context of a complex life.

I want to begin my essay with several flashbacks to my 1994 book, Stepping Out: The Making of Chinese Entrepreneurs (Chan and Chiang 1994). To most of the entrepreneurs in my book, philanthropy was an intentional strategy of upward social mobility through a transformation-from the economic elite to the cognitive elite and the moral elite. They would like to become the conscience of the community; having made their fortunes, they would then desire to enter the elite class. Once there, being part of the elite, they can then get access to some privileged information about the workings of the market. Information is power and knowledge produces profit. Moral reputation is good for business. So, in that sense, altruism is paid off in financial terms. This is the first point I would like to make. Many entrepreneurs, if they have to choose only one project to work on, would like to donate their time, money and effort to education. Why education? They would say in order to make their business move, to join the world, it is very important to be able to upgrade the overall quality of 
the citizens in any particular society, and education is the begin-all, particularly, primary education. Education is a moral enterprise. Most Chinese entrepreneurs were poorly educated and they were blocked from the elite which they desire to enter through the back door, so to speak, by donating to education which sometimes rewards donors with honorific titles. This is my second point.

The third point I want to make is a bit psychoanalytical in temperament. Chinese people who haven't made a lot of money often tell themselves, rightly and wrongly, that those who have made a lot of money exploit those who haven't made a lot of money. This is very Marxian. So, how do they rationalize their conduct of exploitation of others? I think businessmen know that they need not talk about it, as it is a sort of unspeakable truth. So, what do they do? They probably want to gain a certain psychological tranquility, certain self-comfort, certain self-consolation, and one way is to "give back to society" what they have made from society. On the other hand, by doing this, now that they have made it, financially, it would be very important for them to spend the rest of their lives on construction of self image, on "looking good" - to be a good man, a man with a good heart. By doing this, they will be asking for some kind of moral pardoning. Maybe they are also seeking moral glorification.

The fourth point I want to make is in terms of a question: now at the age of seventy or eighty years old, how would they like to be remembered by others? I say: as a man of virtues. There is a very deep symbolic meaning here. Maybe there is a quest for symbolic immortality. Some people gain immortality by contributing money, other people, by building monuments and spectacular skyscrapers, by giving birth to a lot of male children, depending on your ethnicity and your class location in society. Schools and universities don't disappear. They are not as perishable; they are "good goods" because they last. They are durable.

A very brief personal moment: when I was on the flight from Hong Kong to Singapore in 2009 for a speaking engagement, it suddenly occurred to me that my father's name is Chan Yan, or Ren in Putonghua. "Ren" in Chinese is benevolence, which, you may agree with me, is a central concept of Confucianism. What is "Ren"? "Ren" is basically about handling relationships between me and not me, me and others. That is the central idea. If we all can handle that well, we would have gone a long way toward construction of a harmonious society. I'd like to look at philanthropy as a case of altruism, or what social psychologists call "pro-social behaviour" or "helping behavior". Of course, the opposite to altruism is egoism, selfishness, selfcentredness. Altruism as moral commitments on the one hand and egoism as pleasure on the other may not be an either/or. As Etzioni (1988, p. 67) maintains, they are a judicious mix, a balance. I think in all societies, at all times, there have been social discourses on the dialectic of altruism and egoism. These discourses cut across all disciplines and strata, bringing together scholars and laymen, individuals and society, men and nature-hopefully also moving people into a higher realm of human existence which, I reckon, is spirituality. And of course being spiritual is not the same as being religious. There is a very clear distinction between the two.

Recently, I have been writing about cosmopolitanism which, I argue, would be one important pathway to world peace. Sontag (2003) wrote a brilliant book with a brilliant title, Regarding the Pain of Others. Her conclusion is that, unfortunately and lamentably, we do not, in general, automatically feel the pain of others. Someone is bleeding right in front of you, but you do not necessarily feel the pain because we are divided by our bodies. I cannot enter your physical body to feel your pain. She concludes that we do not naturally feel others' suffering. It is not an in-born aptitude, although sociologists try to remind us there is such a thing called "sympathy" or "empathy". And sociologists invented a graphic term for it, "role taking", taking the role of others. The layman term is "can I step into your shoes and see your plight from your point of view?" This is powerful. So I would feel you within you. That is role taking. But it is not an inborn ability, it has to be learnt. It has to be cultivated, internalized. It is one thing that I want to do good, it is quite another thing to actually start doing it. Scholars talk a lot about things without actually doing them. And then you have some people doing it without talking too much about it. Commitments and action make up another binary (Etzioni 1988, p. 74).

Any inquiry into altruism, philanthropy or doing good would usually revolve around a few very simple, basic questions. Why would I help? Why should I help? Helping whom? On what project? For how long? What are my commitments? Now that I have already started the project, how long would I stay in it? Can I get out? When? How? Some people have been working on a charity project for a number of years and they have become what I call "a slave to altruism", "a slave of virtues" who have tilted the balance too far. There will be a time when they want to be a free man, free from being virtuous because it is now a burden, a trap. Or they would rework the balance, and swing back to egoism and pleasure.

Before writing this essay, I did a life history case study of a Hong Kong philanthropist, an educationist: Francis C.K Lee. I had spent seven hours non-stop with Francis. We started from mid-afternoon and talked all the way through dinner in a Singaporean restaurant. It was a very long interview. Mr. Lee is not your Li Ka Shing though they have the same surname in Chinese. He has donated money to the building of two primary schools. One was 
named after his father, the other, his deceased wife, both being an integral part of his "sphere of the intimate" whereby the family is one of the most strategic and crucial contexts (Etzioni 1988, p. 82). He is an owner of a typical small and medium enterprise (SME), not a tycoon who has long been treated as a "hero" in academic studies. Mr. Lee certainly is not one of them; he is an "unsung hero" in overseas Chinese studies. One of the reasons I picked him for my case study is that I wanted to move away from big-time donors whom I had already written about in my book Stepping Out. I want to study those who are sort of in the middle realm. They are not high up there, they are in the middle, in between. Sociologists are fascinated with those who are in between. They are not upper, they are not lower.

I am trained as a social psychologist in the Chicago school of sociology tradition. I have been reading people like William James, George Herbert Mead, Charles Cooley, Robert Park, etc. I am also a family sociologist. I am fond of using classical sociological theories to make sense of what is happening within the family, including my own family. And I always look at marriage as an ideal type of a human pair, a dyad, a two-some embedded in a lager whole, be it clan, kin network, community, society, the world.

I would like to frame my essay largely in terms of the exchange theory (Levinger 1982). In fact, the second part of the title of my essay is "Philanthropy as Exchange". Three simple words. There are several basic postulates of this theory. One is that human actors seek to maximize reward and minimize cost. But humans don't just maximize and minimize; they try to strike a balance, which, as a postulate, is a critique of the exchange theory. Another postulate is that a rewarding relationship will continue and, conversely, a costly relationship will discontinue. In the mind of an actor, there is something I call "mental calculus", a certain kind of what economists call cost-andbenefit analysis, which is supposedly rational (if by acting rationally one means using information that is available, drawing proper conclusions from it, and so on [Etzioni 1988, p. 73]), intentional, deliberate, a kind of rational intelligence. It is pure economics which we sometimes call "rational choice".

"To be or not to be, that is the question." To give or not to give, that is the question, we ask ourselves. Anytime we have this question to answer, we enter into a certain kind of deliberations. One simple example of altruism is donating blood. I do not know how many of you had the experience of donating blood. You have to ask a lot of questions. What are the costs of donating? Costs of time, energy, and blood. And there is a cost of not donating, be it guilt or shame, two rather strong emotions among the Chinese. And there are benefits of donating: you feel good about yourself, your bolster your self-worth, you raise your self-esteem, you contribute to your self-growth, self-actualization. And there are benefits of not donating: saving time, saving the pain of the needle.

Let me now do some theoretical work. Let's look at something we call the "pair". It is a dyad, a two-some (Fig. 1). I call that the schema of person-other relationship. You draw two circles, call one circle, $\mathrm{P}$, and the other, $\mathrm{O}$. There is a middle area, an overlapping of the two circles.

Fig. 1 A $\mathrm{P}-\mathrm{O}$ schema

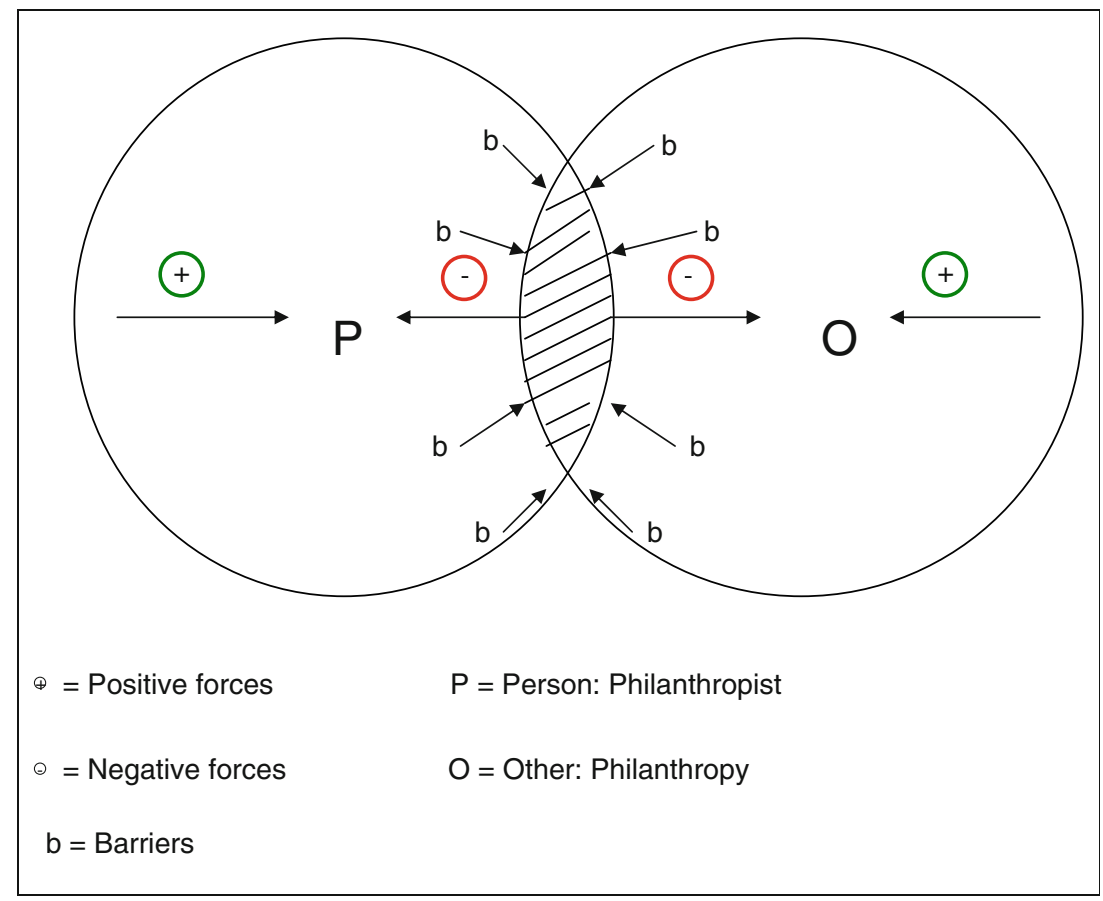


The $\mathrm{P}$ is the donor, the person who does good, the altruist, the philanthropist. The $\mathrm{O}$ is the other, the project of philanthropy, something that we do, it is an act, for example, to build a school, to donate a kindergarten, a museum. Then, there are forces that push the $\mathrm{P}$ and the $\mathrm{O}$ toward each other, which I call the positive forces.

Of course one ideal scenario is when circle P overlaps circle $\mathrm{O}$, totally, completely-in fact one circle is on top of another circle (Fig. 2). (But "ideal" according to whom? From whose point of view? May this state not be the best, the ideal?). At this moment, I and my philanthropy cannot be distinguished. Two rolled into one. I become a 24-hour philanthropist, not part-time. This is amazing, like falling in love. Imagine this man $\mathrm{P}$, this woman $\mathrm{O}$, and they are together, two bodies, two minds, two souls, combined to become one. The two are now madly in love; I cannot separate myself from her, and vice versa. We see each other every minute, every second. That is romantic love, which, in its extreme form, may represent something that is sick, mad, abnormal. There are forces pushing them to stay together, to be stuck with each other-or the philanthropist is "stuck with" his philanthropy. Of course, there are also forces pushing $\mathrm{P}$ and $\mathrm{O}$ away from each other, meaning that there are some reasons or forces because of which the donor cannot be too fully engaged in his charity work, which may turn out to be a good thing, a balance, as too much of a good thing is $b a d$.). We call these negative (and positive) forces.

Let me move on. Let's look again at the pair, the $\mathrm{P}$ the person, the donor, and the $\mathrm{O}$ the other, the act, the charity project. We can talk about an attraction to the relationship. What attracts me to this $\mathrm{P}-\mathrm{O}$ relationship, what attracts me to this project, what attracts me to philanthropy? I would argue, recalling the exchange theory, that attraction is directly associated with its perceived rewards, and inversely with its perceived costs, emphasizing the significance of perception of things, of subjectivity of the person as perceiver, as cognitive man. Rewards are positive outcomes, referring to the receipt of resources, such as love, care, status, information, goods, security, support, and so
Fig. 2 Forces of attraction in $\mathrm{P}-\mathrm{O}$ relations

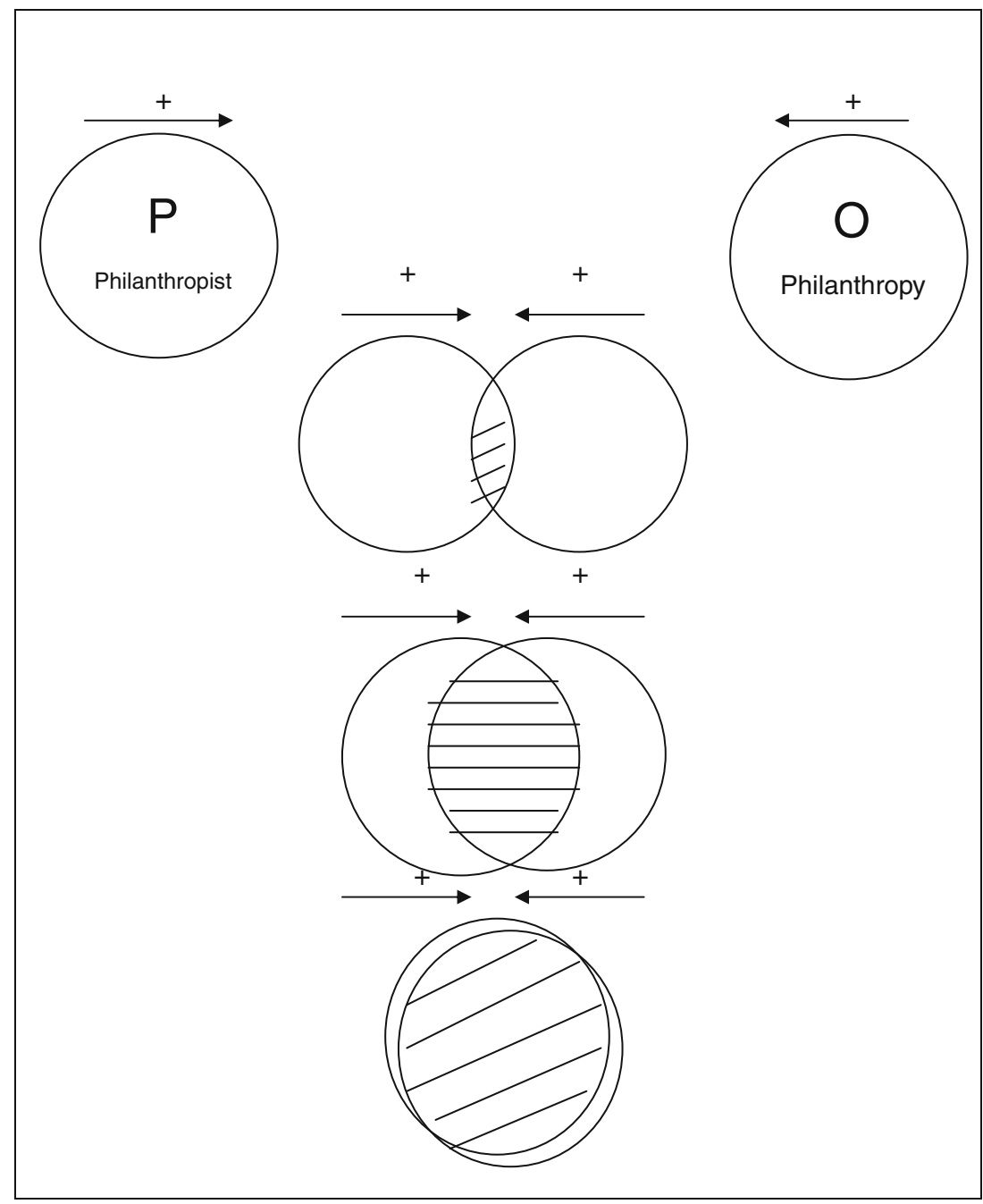


forth. Costs refer to the expenditure of time, energy and, of course, huge amount of money in the case of philanthropy and charity. You would terminate this relationship of the pair if there is a drastic shift in perceived costs and rewards. In other words, you will stop donating when the costs are higher than the rewards, among other factors or circumstances.

What is in it for me? What are my rewards? What are the attractions to me in order for me to go into a pair of relationship, in order to "do philanthropy". As I said earlier, one of the rewards is information, if I could get access to an item of "perfect information" by virtue of the act of philanthropy, by being able to make an entry into the elite-and I also know that knowledge is power, especially in the market of capitalism. Another reward would be status, symbolic standing, personal reputation, social location in the community, particularly in a highly stratified society in both materialist and symbolic terms. And then you have other rewarding things like social honor, cultural honor, meaning of life. Here I am intimating existentialism, self-actualization, hierarchy of needs, and so forth. The sociology of emotions tells us one of the most profound rewards in doing good is joy, the pleasure, the enjoyment, the satisfaction, the happiness in doing good. It is better to give than to take.

What did Francis Lee tell me in the interview? He recalled his first encounter with philanthropy as a schoolboy passing by the front door of a famous charitable organization in Hong Kong, Po Leung Kuk, which was first set up to protect women:

Maybe it's destiny. When I was about 10 to 11 years old, I passed by Po Leung Kuk and wondered what it is. I knew it was a charitable organization. I looked at the inscription underneath the Kuk's name. I felt sort of interested in it even I had no idea about its service. So I went back and searched for some information about the Kuk. Later I learned about the historical background of the Kuk; it was a specialized organization protecting women, which has developed over the years into a comprehensive, integrated charitable organization. I had strong interest in the Kuk, without knowing the exact reason. At that time, I told myself one day I would be going to the Kuk to give a helping hand to the needy. This was a memorable recollection for me; at that time I was only a little kid, 10 to 11 years old, still hadn't graduated yet from the primary school.

Francis told me that his businessman-father valued primary education very highly. But Francis was a high school drop-out. His father always complained, "Oh my goodness! What happens to my son?" The young Lee was a shameful and guilty son. Francis didn't do well in school but he inherited his father's business, transformed it and made an enormous amount of money:

My academic results were not good when I was in high school. This made me feel disappointed about the teachers and the curriculum. I could not tolerate the stupid textbooks, they were too easy for me. I didn't think the teachers cheated to make a living, but I did think that their educational levels were too low. This was how I grew up. So you can now imagine why I read all sorts of books except textbooks.

I was so disappointed about education. During school days, I disliked going to school, which planted some sort of thoughts in me that I had never fully expressed.

While growing up as a schoolboy, I showed full competence in all aspects except in my studies. For example, I was good at sports. However, my father is a very traditional man, he is very smart. When he was very ill, he told me I would not be able to continue my studies. Even he didn't say it, I truly understood how disappointed he was with me. On the one hand, I failed in my studies. On the other hand, he could never understand why his son was so stupid. No matter what, in my father's eyes, I was not ambitious, making him exceedingly disappointed. I am his only son, but we had no communication at all. How would fathers and sons communicate at that time?

As a failed son, Francis felt compelled to make good, to make it right:

"Gee, I remember what my father always told me and I agree with him that education is important, so I put out money to build two schools, one named after my father and the other, my wife-to remember two loved ones, both deceased now." Francis's philanthropy was an affirmation of his father's belief, which he hoped to transmit to the next generation. Francis's wife died of a stroke and heart attack. He was feeling intensely guilty about not having been able to treat her sickness fast enough. He felt a lifelong guilt. His wife loved kids and she liked to spend a lot of time with them. So he built the second school to name after her. He told me that every time he went to the school, when he saw the children, he experienced the kind of deep inner joy that his wife often spoke of. He said, "When I come to this school, I know this is my wife's school. In this school, this office (where we did the interview), it is almost like a kind of communion between me and my wife, who is long gone, in heaven-a communication between people in this world and people in the other world. This gives me enormous satisfaction". Francis has long obtained his rewards:

I truly respected my father. He started his business from scratch. He was upright for his whole life, with 
an enthusiasm towards education. He helped numerous people in need. I fully understand that there was a regret deep down his heart, as he could not go to school due to the political circumstances at the time. The passing away of my beloved wife, Fanny Tsang, broke my heart. I found myself feeling terribly guilty. There were lots of problems in the hospital. My wife was only 47 when she met her death. In the past, she always accompanied me to the school I built for my father during weekends, sometimes with her dog. She was so kind, her colleagues loved her. Once, I saw a little girl queuing up waiting for her snack; she looked so adorable. At that moment, I made a wish to myself to build another school to remember her. That year, after Fanny passed away, I could not work at all. From that year onwards, I was officially retired, I closed down my business, sold it, and resigned from work.

My wife was enthusiastic about education. She had no sons or daughters, which made her treat her students like her own children. There are newcomers at the school every year, which is why I use this way to remember her.

Both father and son did not finish high school. Francis's investments in schools were motivated and moved by the bondage of love with his father and with his wife. Love is almighty. Love is a many-splendored thing.

Francis said that he has learnt a lot from philanthropy; altruism has given him a lot, ten times more than he has given away. He is feeling indebted to altruism. He also said that Hong Kong has been very good to him; it is in Hong Kong where he made a lot of money, so he wanted to give back. "This is the place where my children were born. I am happy here so I want to give back." He also mentioned that the business world is a "dog eat dog world", it is merciless, heartless, it is capitalism, it is commercialism. The opposite to capitalism, to him, is philanthropy, altruism, charity, giving children an education. Seen in this way, capitalism and altruism almost become two opposite ideal types, though a good sociologist would try to deconstruct the tension between the two, to balance them:

I did a wide variety of things in my life. But among all, I find running schools the most fulfilling. When I meet and play with children, I feel exceedingly happy and excited. I had worked in The Hong Kong Society for the Aged, the biggest organization serving the elderly. But I had never had any fulfillment working there. It was an unending battle. Actually, I have already resigned from many such duties these years. Regarding the rewards...in fact starting from the 70s, I have been doing voluntary work, such as at the Lions Club, Po Leung Kuk, the Hong Kong Society for the Aged. There, I can get in touch with things I do not usually encounter. My horizon is broadened, which money cannot buy. Secondly, it is very pleasant to see children playing at the school, again this is something you can't buy. Thirdly, after several years of cooperation and collaboration with my teaching and administrative staff, I believe that my team is the most outstanding one in Hong Kong. I feel much pride to have formed such a powerful team. What's more, this team can influence the next generation. Money cannot buy these kinds of fulfillment and pride, and the money spent was only a minimal amount. After all, we are born and bred here in Hong Kong...

Pride, pleasantness, joy are strong emotions, which "money cannot buy".

Now let's move away from the rewards, the attractions, to what I call barriers. Looking at Fig. 1 again, these are the arrows all pointing in one direction. When sociologists try to explain why a loveless marriage does not end in divorce, they theorize that one should identify and look at what they call barriers. Barriers are forces that keep the husband and wife in a miserable relationship. The fact that the husband and wife do not love each other doesn't mean they will end the relationship with a divorce. There are probably a lot more loveless marriages out there than we would admit. How to make sense of that? One explanation, socio-psychologically, lies in the strength of the barriers. There are a lot of sociological forces that keep the marriages intact, without the marriages transiting into divorces.

Theoretically, I am saying that even if there is very little delight in a marital relationship, the existence of strong barriers, restraining forces, would create a kind of emptyshell marriage, a prison, a trap, such that the couple inside cannot or would not get out. Some would call this "all form, no substance". Sometimes staying together, remaining married legally in the eyes of community, overrides all other values, including your own happiness, the happiness of your wife, of your children. Both of you know that you are not happy with each other, but that is not a good enough reason to get a divorce. Why? Because there are social barriers, as the sociology of relationships has told us. For example, many of us would say that we should not divorce because it would harm the kids. Or, we should not divorce for neighborhood respectability. Or, divorce is too much of a stigma. It is still a stigma in a lot of Chinese societies world-wide. Or because of religious reasons, people in the church may say. In other words, I ask a very sociological question here: what would others say about us getting a divorce? So far, I am drawing an analogy to compare marriage as a pair with the situation of a donor stuck with a project which he cannot drop because of 
barriers, or forces that keep him in and keep him from getting out. Barriers derive themselves from the social structure. The sociology of relationships would call these barriers commitments, obligations, devotions. It is particularly so when the donor has made a public declaration, an announcement, of his charity work which takes on a force of its own and would become a new psychological force against termination of the pair relationship.

So Francis Lee said, "the two schools, because of the names that they bear, cannot fail. I can fail, but the schools cannot. They represent my two only loves in my life. They cannot fail, they must be the best in Hong Kong. They must continue, the show must go on, no matter what." In a very ironic, deep way, Francis, in my view, is locked into this pair of relations, sort of "imprisoned", "caught", "captivated", as a slave to virtues, altruism, philanthropy. The Chinese call this condition "riding a tiger but not being able to get off its back". One cannot stop, period. Let me now tighten the screw a bit even harder. Francis said solemnly, "Professor Chan, I have no successor." He has no successor. The guy is lamenting about it. And I asked "What about your children?" He said, "my children do not have the ability, nor the heart, to be my successor. Let me say, if you do not have the ability, you can learn it, but if you do not have the heart, forget about it." So Francis has given up on the possibility of any of his children inheriting his project of doing things for their step-mother and grandfather. Neither could Francis find a friend who would carry on for him. So he cannot pass his philanthropy to anybody else, not in the family, not outside the family either. This is a dilemma, a real plight. In the past two months, I have not seen him as regularly as before. He was worried that he might die in the same way his wife did. He was complaining about heart murmurs, irregular heart beat, his heart condition:

This is my biggest difficulty. How can I continue my belief, enhance and glorify it? I don't want any of my children to inherit my schools, as I truly know that they don't have such qualifications, neither the benevolence nor the values. Especially in this year, my health condition burdens me a lot. In fact, I have no idea how to deal with the problem, the problem of succession. Where could I find someone who has sentiments toward the schools? As I always say, techniques can be learned, but if you don't have the sentiment toward the school, you will definitely not dedicate your time to the school. If someone does not teach well, I will give him/her tutorials or let him/her attend seminars. We have a team to assist such teachers. Though others are running, and s/he is just walking, s/he will gradually achieve the goal someday and eventually arrive. However, if you lack the heart, or you are not willing to commit yourself, or you dislike children and want to kick them out, how can you be a successful educator? This is impossible. So, if I can find someone who has the right kind of feeling about the school, and with a better vision and health than mine, I am willing to hand my two schools over to him or her. Just like that. But it is not easy to find such a person at this stage.

For Francis, the best of all possible worlds would be that he has children who have the heart and the ability to pick up where he left off. That way, egoism merges with altruism. Many tycoons "cave in" in the sense that they pass on their wealth to incompetent and wasteful children-knowingly. But Francis did not.

Francis continued:

As I mentioned before, other things are not important for me. I am only a passer-by in this world. However, as the two schools are named after my father and my wife, while my own failures are nothing to me, I cannot spoil my father's and my wife's reputation.

He was pursuing an immortality of his own also, being fearful that his children will spoil them all.

The exchange theory has another critical component, the "alternative", the option. Let me make an argument: even if the internal attractions within the pair are low, meaning the $\mathrm{P}$ and the $\mathrm{O}$ are not attracted to each other anymore, and even when the barriers against dissolution of the relationship are weak, the pair will not terminate and dissolve unless one side thinks that there is a more attractive alternative out there. Is there a "third party" or not? "Is there a triad?", I asked Francis Lee. I asked him, "Well, you have been running these schools for years, have you ever thought about any alternative project other than education, or have you ever thought about not doing anything at all? Stop it. Now you have a heart condition. Do you want to be a free man? Do you want to be free from philanthropy, from it all? I have done it, now I stop, I do not want to do it till the moment I die. Can you get some kind of liberation from this bondage to goodness? In other words, do you want to get control of yourself?" He replied, simply, "No, education is my life!" Again a binary: egoism (his health) versus altruism. By then, seven hours had passed, and it was already midnight. We stopped the interview, but I cannot stop thinking back on his clear convictions about education:

What is "Sun Education"? To be simple, the sun is an indispensable element for human beings. Sunlight brings us warmth and light, it shines at humans' prosperity, but the most interesting thing is, whether poor or rich, pretty or ugly, the sun shines on us all and treats us all the same, which coincides with the old Chinese saying "No Child left behind". I hope to 
act like the Sun, to ask for no rewards, but to give anyway. Hence, we use sunlight to symbolize our structure and techniques. We design our own curriculum to educate our next generation, let them experience more, learn from their experience. With good experience, their logical and critical thinking can be developed. Some of our curriculums are brilliant, which is underpinned by our basic philosophy of education- "The Sun Education".

Francis's two schools have been for many years a training ground for schools and teachers in Hong Kong and from overseas, thus widely and wildly sowing the seeds of his "Sun Education" philosophy.

I am completely aware of the fact that my whole theoretical approach thus far has taken on an individualistic orientation, meaning I consider social exchange in terms of a reciprocity that occurs within a dyad, a pair. It is a "restricted exchange" between two objects, within a particular relationship. But being a sociologist I would be the first one to argue that in future theorizing and research about philanthropy, we have to move away from this individualistic orientation and toward a more collectivistic orientation. We have to look at the pair interaction as part and parcel of a social net within a wider structure. We have to move from the restricted exchange to a generalized exchange, which would enable us to focus on the influence of the community and social networks. We should work toward the sociology, even the political economy, of altruism.

One of my theoretical concerns is with the unit of analysis in studies of altruism. By moving away from individualism to collectivism, I am moving away from restricted exchange to generalized exchange. I want to build theoretical bridges between individualism, a pair, the donor on the one hand, and his or her project, social networks, community, society, nation, even beyond nation, a kind of transnationalism or cosmopolitanism on the other hand, which may bring us all the way up to the realm of the spiritual. As I said earlier, the realm of the spiritual is not the same as the realm of the religious. With that, I will return to the origins, the roots, of humanity.

How should future research on philanthropy proceed? The first point I want to make is about the importance of theory, especially in sociology and anthropology. Anthropology in fact has a long history of studying the act of giving and the meaning of gifts. The anthropology of gifts has a very long tradition. So I want to bring theory back. In terms of choice of research methods, I want to go back to the Chicago school of sociology. I want to do anthropology, I want to do fieldwork, and family case studies. Like studying Francis, I would put him, the P, in the network of the others. Here, one can think of several concentric circles. This is Chicago school, which is also very Chinese in terms of confucianism. You put the individual, the social person, in the centre, and then you draw a lot of circles, outreaching concentric circles. The innerest circle surrounding the self is where you find "the sphere of the intimate", which includes family members. I really do not believe one can study philanthropy without understanding how the family works. We should not just do case studies of individuals, rather, we have to do family case studies, family biographies, family life histories.

Again, on theory and theory-building, my case study enables me to arrive at a conclusive moment now, which I cannot better describe than quoting Etzioni (1988, p. 83):

The concept of a single over-arching utility disregards a major human attribute observable in the behavior under study: people do not seek to maximize their pleasure, but to balance the service of two major purposes - to advance their well-being and to act morally. The quest for balance is evident in that, as individuals advance one major over-arching concern, they continuously strive not to neglect the other.

The second point I want to make pertains to comparative studies. How should I put it? Back in graduate school, my professors told me many times that what characterizes sociology is its method of comparison. But I very quickly realized that my professors themselves had never done any comparative work. He told us about it but he didn't do it. Why? Because comparison is very difficult to do. My professors also told me, "Do not do surveys, try to do fieldwork, anthropology, ethnography." I later discovered that my professors had done almost no fieldwork either because fieldwork requires you to be there; for surveys, you can use research assistants who work in the comfort of a lab to collect second-hand data for you. I think it is very important to do ethnography, fieldwork and comparison. We have to keep comparing, for example, Chinese families with non-Chinese families, to discover the particular or the unique among the general, and vice versa-in order to say "all philanthropists are the same, and different". They are all the same, everywhere, but they are different in their own ways. By doing comparison and contrast, we discover the unfamiliar amidst the familiar, and we can also begin to deconstruct certain approaches and certain ideas long ossified by essentialists and culturalists. Here, I would like to refer to a book titled A Study of the Development of Charity Undertakings in China edited by Xu (2005). The editor tried to look at philanthropy in China, but he did it by making comparisons, all the way. So, you have China here, and Taiwan, Singapore, Canada, and the United States there. He did that intentionally, so that he would be able to draw conclusions on China on the basis of very good comparative data. 
Let me end my essay with a comparison of three places: Hong Kong, Singapore and Canada. I was born in China, grew up in Hong Kong, educated in Canada, and then went to Singapore in 1987 to teach for 14 years. Then I returned to Hong Kong in 2001 as a return migrant. I am intensely concerned about these societies. I always look at these societies through comparative lenses. If you look at the private donations in these places, there is a rough ratio: if Singapore is one, Hong Kong is seven, and Canada is eighty-four. Canada has a population of thirty million people, but they have twenty-two million donors, seventyone percent. And the average amount of money donated by Canadians, as individuals, is two hundred and sixty Canadian dollars per year. What do you want? Do you want to work on big time donors, like in Singapore and Hong Kong? Or do you prefer the Canadian way whereby philanthropy is everybody's business except those who are very poor? I guess the thirty percent of non-donors are the very poor people who cannot afford anything in their own lives but waiting for others to help. The seventy percent of donorship is a staggering figure. I think all societies should move toward that model rather than relying on the big-time tycoons. So I am not interested in the Li Ka Shings, I am interested in the Francis Lees. The more Francis Lees, the better. I am interested in those who are in the middle or even those in the below. I want to do sociology of everyday-life altruism, or sociology of commonplace philanthropy. We all realize that, yes, there is indeed a private self, a me, an egoism, such that I must look after myself, my family, my domestic world, my private world, but there is also a larger world out there, a community, a society, a universe. If I can only tell myself that there is a deep, deep relationship between the small world and the larger world, the world of the sun, that the two worlds coexist interdependently... but that takes a lot of education and re-education, an enormous amount of re-socialization. So altruism must be a way of life for each and every individual so that we are not at the mercy of the big-time tycoons and we are not dependent on the heroes. Giving must be part and parcel of being human. So let us go back to Sontag's book. If you see somebody in pain, somebody suffering, you can feel it. You can feel it not because of an in-born ability, but because you have learnt it through education, socialization, sensitivity training. Giving has now become a way of life. It is as natural as breathing air. Or as basking in the sunshine on the beach.

Open Access This article is distributed under the terms of the Creative Commons Attribution Noncommercial License which permits any noncommercial use, distribution, and reproduction in any medium, provided the original author(s) and source are credited.

\section{References}

Chan, K. B., \& Chiang, C. (1994). Stepping out: The making of Chinese entrepreneurs. Singapore: Prentice Hall.

Etzioni, A. (1988). The moral dimension: Toward a new economics. New York: The Free Press.

Levinger, G. (1982). A social exchange view on the dissolution of pair relationships. In F. I. Nye (Ed.), Family relationships (pp. 97-122). Beverly Hills: Sage Publications.

Sontag, S. (2003). Regarding the pain of others. New York: Farrar, Straus and Giroux.

$\mathrm{Xu}, \mathrm{L}$. (Ed.). (2005). A study of the development of charity undertakings in China. Beijing: Chinese Social Sciences Publishing House (In Chinese).

\section{Author Biography}

Chan Kwok-bun is Chair Professor of Sociology, Hong Kong Baptist University. He earned his doctorate in sociology at York University, Canada. He is former Head, Department of Sociology, and former Director, David C. Lam Institute for East-West Studies, Hong Kong Baptist University. He is also former President, Hong Kong Sociological Association (HKSA), and former Editor of Social Transformations in Chinese Societies, an official HKSA journal. An expert in family studies, economic sociology, and migration, Chan is an author of 60 journal articles, 55 book chapters, and 40 books. He is editing for Springer The International Handbook of Chinese Families. 